\title{
Understanding Adoption in Smallholder Agriculture: Perception \& Row Planting Teff in Ethiopia
}

\section{Tadele Fayso*}

The Academic Department of the School of Social Science and Human Studies, Atlantic International University, USA

Submission: November 21, 2018, Published: December 10, 2018

"Corresponding author: Tadele Fayso, The Academic Department of the School of Social Science and Human Studies, Atlantic International University, Pioneer Plaza, Fort Street Mall 410, HI 96813, USA

\begin{abstract}
Technology adoption is a complex and a dynamic process that is determined by many factors such as perceived characteristics of the technologies, farmer circumstances and conditions. This study aims to understand farmers' perception of teff row planting practice and adoption of the practice in four regions of Ethiopia. Quantitative cross-sectional design was used for the study and Teff growing farmers from 6 districts of Amhara, Oromia, SNNP and Tigray regions of Ethiopia were participated in the study. Two stage probability sampling method was used to select study districts and participants. Structured questioner was used to collect quantitative data. Descriptive statistics (frequency and percentages), Kruskal-Wallis Tests and biserial correlation were computed to understand farmer's perception regarding teff row planting practice and adoptions difference among farmers in different districts and perception factors affecting adoptions of teff row planting practice respectively. According to the finding of the study farmer's perception regarding teff row planting varies across the different perception parameters. The result shows that $85.8 \%$ of the farmers perceive that the practice is labor intensive, $95.6 \%$ of the farmers perceive that the practice is profitable, $85.8 \%$ of the farmers perceive that the practice productive, $95.7 \%$ of the farmers perceive that the practice is profitable and $95.6 \%$ of the farmers perceive that the practice is quality. However, among the total respondents only $57.7 \%$ of the respondents adopted the practice and also KruskalWallis Tests statistics shows that there is significant difference among districts in adopting teff row planting practice. The result also revealed that perceived model/non-model status, perceived productivity of the practice, perceived quality of the produce and easiness to understand the practice significantly correlated with adoption status. In the light of the findings, recommendations are forwarded to improve uptake of teff row planting practice and benefits gained from row planting practice in the process of teff grain production.
\end{abstract}

Keywords: Agriculture; Adoption; Ethiopia

Abbreviations: ADLI: Agricultural Development-led Industrialization; MoA: Ministry of Agriculture; SNNP: Southern Nations, Nationalities and Peoples; FTCs: Farmer Training Centers; RBoA: Regional Bureaus of Agriculture; IFPRI: International Food Policy Research Institute; ATA: Agricultural Transformation Agency; SS: Sample Size

\section{Introduction}

Since 1943, agricultural extension services in Ethiopia has sought to support farmers to adopt new techniques, inputs and technologies [1]. While some changes have been advocated for decades, adoption is mixed [2]. This paper focuses upon one, relatively recent addition to the agricultural extension repertoire: the promotion of row planting for the cereal teff. A number of different approaches have sought to understand adoption of this planting methodology: cost, labor and time, yield increase, modality of promotion and worldviews. We review these findings and contribute a multi-site study exploring perception.

Understanding the promotion of adoption of new ideas, approaches and technologies has been a long-standing research question [3-5]. A lack of understanding change within smallholder contexts is not due to a lack of research. Two and a half decades ago Kebede et al. [6], attempted to explain why Ethiopian farmers were not adopting new technologies, some of which continue to be promoted by the government today, such as fertilizers. The research conducted by Kebede and his fellow researchers is one of many that provides correlations, associations and linkages to explain why change does or does not occur. Despite decades of study, low adoption rates remain "not fully understood" [7]. As this paper demonstrates, the primary causes, the best promotional modalities and the crucial barriers remain debated.

\section{Context}

The foundation of agricultural extension is informed by three adoption paradigms: innovation diffusion, economic constraints, and adoption perception. The main assumption of the innovationdiffusion model is that the problem of adoption is one of asymmetric information and very high search cost and adoption will occur if the newly introduced practice, input or technology 
is technically and culturally appropriate [8-10]. The economic constraint paradigm suggests that input fixity in the short run, such as access to credit, land, labor or other critical inputs limits production flexibility and conditions technology adoption decisions [9-11]. The adoption perception paradigm suggests that it is not information or cost, but the subjective understanding of the practice, input or technology [12-14], and thus adoption affected by how the change is perceived $[15,16]$. Agricultural extension programs aimed to promote new practices, inputs and technologies are commonly designed to address barriers respective to the driving paradigm.

Alternatively, non-adoption may be founded in a rejection of the newly introduced practice, input or technology. The change may be irrelevant to needs, not suited to the environment or conflict with other important activities $[13,17]$. In response to this, research and agricultural extension work, starting largely in the 1990s, increasingly recognized farmers as partners, not just as a client or a customer, in developing new agricultural technologies because farmers perceive technologies differently, and have different concerns than researchers and extension agents. Farmer participation in design operates to provide insight into the effectiveness of adoption [18]. In the 1990s, the participatory research paradigm helped scientists to understand how farmers experiment on their own and to seek partnerships with them in developing technologies [19]. Other benefits accruing to research stem from the fact that users are active innovators, experimenters and seekers of research knowledge in their own right. They play different roles when they work with researchers and can at one time be colleagues, students, advisors or even extension agents [20]. By working with farmers, researchers can build on their knowledge while at the same time being more sensitive and responsive to the needs of their clients and hence enhancing the probability of appropriateness, and therefore adoption.

\section{Adoption of row planting teff in Ethiopia}

Ethiopia is predominantly agricultural economy. Agricultural accounts for nearly half of total GDP, exports are dominated by agricultural products and more than $80 \%$ of the population depends on various forms of agricultural production for their livelihoods. The Government of Ethiopia's Agricultural Development-led Industrialization (ADLI) policy framework outlines a phased development: first focusing on output growth in agriculture, through intensification, which will support industrialization objectives as agricultural growth and mechanization will shift the labor market. In practice, ADLI focused on increasing land productivity in cereal production via improved inputs and extension services. Recent reforms highlight the Government of Ethiopia's commitment to decentralizing extension management from the federal level to the regional state, district, and community levels, as well as leveraging partner organizations in the civil society sector and development community for support.

One of these partners is Digital Green, which in 2012 partnered with the Federal Ministry of Agriculture (MoA), to pilot video based agricultural extension approach in 14 districts of four regional states - Tigray, Oromia, Amhara and Southern Nations, Nationalities and Peoples (SNNP). The Digital Green approach is a technology-enabled means of agricultural extension that brings together researchers, development practitioners, and farmers to produce and share locally relevant information. In addition to row planting teff, the video also covers seed variety, planting, spacing, and fertilizer use. The mediated screenings are conducted at local group levels, at pre-determined locations and times convenient to the group members (mostly evenings). Using video as a medium for sharing improved agricultural practices to overcome challenges posed by illiteracy, Digital Green is hoping to replicate the positive, cost-effective results of this approach seen in India [21]. From 2015-2018 the project was being expanded to cover 68 districts, with support from the Bill and Melinda Gates Foundation. While the work of Digital Green covers a number of crops, this research focuses specifically on one, teff.

Teff (Eragrostis tef), a cereal grain that is included grass family of Poaceae, is endemic to Ethiopia and it has been widely produced for many centuries [22]. Teff is commonly grown in the altitude ranging from 1800 to 2100 meters above sea level, with the major producing areas being Amhara, Oromia, Tigray and SNNP regions. Teff is the most important cereal, both in terms of production and consumption in Ethiopia. Relative to other cereals, teff fetches relatively high prices on the market, making it an attractive cash crop for farmers. It is nutritionally rich with high levels of iron and calcium, as well as highest amount of protein among cereals consumed in Ethiopia. According to the CSA [23], teff accounts for the largest share of the cultivated area (27.73 percent in 2014), followed by maize (with 20.80 percent). More than six million households' livelihoods primarily depend on the production of teff [24].

Conventionally, when teff is planted, its seeds are broadcasted on well ploughed land and lightly covered with soil for germination to occur in shorter period of time. Using this broadcast approach, it is estimated that farmers' use of teff seed at a rate of $25-50 \mathrm{~kg}$ per hectare [25]. Research indicates that this practice reduces the amount of grain production due to the uneven distribution of the seed, as well as competition among plants for inputs such as water, sun light and nutrients. It is also makes weeding more time consuming after the maturity of the plant [26]. The result is the reduction of teff yields at the harvesting period. Teff is used to produce the nation's staple dish enjera, which accounts for 11 to 15 percent of all calories consumed in Ethiopia [27,28]. More than $60 \%$ of the Ethiopian population uses teff as their daily staple food.

\section{Justifications and challenges}

The Government of Ethiopia, non-governmental organizations and researchers have respectively contributed reasons why farmers ought to change from broadcasting to row planting for teff. In what follows, we briefly outline these justifications as a means to contextualize the findings on the perception of this practice. In addition, we highlight reasons that have emerged about why adoption has been low, and at least for row planting teff, remains 
relatively low despite a strong push from governmental and nongovernmental actors.

\section{Yield}

In 2009, based at the Debre Zeit Agricultural Research Center, Tareke Berhe began experimenting with teff row planting and later confirmed that reduced seed rate and row planting could potentially double teff yields. At the time, the ATA argued that the lack of modern planting technologies, limited agricultural extension resources, and a resistance to adopting practices resulted in low adoption rates for these types of technologies [29]. Starting in 2011, the Ministry of Agriculture (MoA), ATA, and the Regional Bureaus of Agriculture initiated a large-scale trial of this approach. Demonstrations were made with 1,430 farmers and 90 Farmer Training Centers (FTCs), which resulted in 50-80\% yield improvement compared to the national averages. Based on the success of these initial trials, the Transformation Council and the Ministry of Agriculture encouraged the Regional Bureaus of Agriculture (RBoA) to popularize these technologies in highyielding zones during the 2012 planting season. As the federal and regional infrastructure has expanded, as well as capacity and resources for agricultural extension expanded, adoption has only moderately risen. Yet, according to the ATA [25], most of the farmers who adopted new teff row planting experienced yield increases, across all regions.

Research conducted by the International Food Policy Research Institute (IFPRI), also found yield increases, but less than the $200 \%$ suggested by Dr. Tareke Berhe and also less than the 50$80 \%$ found by the ATA. IFPRI's field studies showed an increase of $22-27 \%[26,30,31]$. There are indications that in less than ideal settings, akin to reality of smallholder farmers, yield increases may be even less significant, as low as $2 \%$ [32].

\section{Economics}

According to research done by the Agricultural Transformation Agency (ATA), farmers could optimize the cost of input use and yield by reducing the seed rate from 25-50 kilograms per hectare using broadcasting application to 3-5 kilograms using row planting [28]. The economics of smallholder farmers, therefore, will become more efficient in terms of operational costs and more profitable due to increased productivity.

\section{Access to information}

The use of fertilizer in smallholder Ethiopian contexts is arguably the greatest success in rural extension advocacy, at least in terms of farmer adoption [33]. Statistical analyses conducted by Yu and Nin-Pratt [34], identified knowledge and access as key barriers to adoption, while past education and experience as well as household wealth may facilitate adoption. Yu and NinPratt [34], also found that rural agricultural extension services supported farmers to overcome knowledge barriers in adopting a new technology or practice, the utilization of fertilizer being one of the changes advocated. The influential role of extension workers, past experience and education are confirmed in other studies Ahmed [35].

\section{Modality of promotion}

Ethiopia's agricultural extension system is staffed by community-based personnel, commonly working out of a Farmer Training Center (FTC), wherein training and demonstrations are offered. Farmer field schools are commonly thought of as important mechanisms to support change, which have roots both in perspectives assuming farmers to be rationally self-interested and in social learning theories. Although there have been hundreds of evaluations of farmer field school designs and implementations, the collective findings are inconclusive and debated [36]. The diversity of opinion on farmer field schools as a modality for encouraging adoption can be demonstrated by the World Bank suggesting they have had no significant impact and discontinuing support of them [37], while the Food and Agriculture Organization of the United Nations suggests the results are remarkable and lasting [38].

This debate continues [39-41], and a detailed analysis of the respective approaches and findings are beyond the scope of this work. Worthy of note, however, is that a systematic review of farmer field schools found that while some impacts occurred at the individual level as a result of farmer school activities, there was no evidence of experience-based adoption spreading to neighbors [42]. Yet, while little spread of agricultural practices took place as a result of farmer field school engagement, other research finds that proximity to new ideas in other spheres, such as microenterprises, occur in clusters [43], suggesting experiencebased adoption may be more likely with some ideas, technologies and practices than others. For the moment, the Government of Ethiopia, and its partners, has created a system based upon the farmer field school model and one which assumes dissemination will occur organically from farmer to farmer.

Waddington and White [36], with reference to farmer field schools, outline that outcomes are dependent upon "training suitable facilitators, targeting appropriate farmers to attend the full training schedule and undertaking activities to promote dissemination and diffusion." Of those studies that focus on the role of knowledge and awareness for changing behavior, a limited number take into account the approaches and effectiveness of the teaching, learning and advocacy processes. Those that include this in their evaluation confirm that the teaching methodology is a highly influential in the agricultural adoption process [44].

\section{Worldview}

In addition to the importance of knowledge, Yu and Nin-Pratt [34], also find a trend of risk aversion, whereby farmers prioritize risk mitigation, resulting in significantly different ways of thinking about new technologies and practices. For example, those that do adopt changes advocated by extension workers may not adopt them in full [45], as farmers test out new technologies and practices in a systematic and progressive fashion. This approach enables farmers to see if such a change will be absorbed into the existing system or pose unknown, potentially irreversible, disruption to the entire system. 


\section{Agricultural Research \& Technology: Open Access Journal}

Building upon this, Cochrane [46], utilizes the concept of 'worldviews' to explore how farmers and development organizations assess change differently. Different systems of logic, rationale and priorities exist, which help explain some of the responses from farmers that go misunderstood by agricultural extension staff [31]. For example, Cochrane [46], found that farmers used a small plot of land for testing row planting suggesting the issue was not knowledge or a lack of conviction. Rather, farmers are evaluating change using a different metric than that presented to them by development organizations and the government. Cochrane [46], also points out that, at least to some degree, access to information is not a key barrier because farmers use row planting for maize, and thus the method is not unknown to them.

\section{Other factors}

One unique analysis done by Ersado et al. [47], suggests that non-agricultural factors, such as time spent ill, caring for the ill and problems associated with access to healthcare significantly negatively influence the adoption of agricultural practices. Similar to environmental, political, legal and economic changes, these health-related factors are not often included in research efforts seeking to understand changes in smallholder agricultural practice. However, some agricultural innovations, such as microdams, Ersado et al. [47], find, may decrease adoption of new technologies as it increases health challenges (such as malaria) and reduces availability of time due to illness.

\section{Methodology}

Rogers and Shoemaker [48], identified important variables that determine the rate of adoption. One of these variables is the perceived characteristic of the innovation or technology. Some technologies are adopted more rapidly than others because the farmers perceived them to have different characteristics. Thus, understanding farmers' perceptions of a given change has long been understood as a crucial component in the generation and diffusion of new practices, inputs and technologies. In seeking to assess perceptions of row planting teff, this study utilizes a quantitative cross-sectional design, collecting data from six teff growing regions in Amhara, Oromia, SNNP and Tigray regions. The study covered farmers taught by Digital Green in the 2014/15 planting season, totaling 13,847 farmers.

The sample size (SS) was determined at 95\% confidence level ( $\alpha=0.05$ ), $5 \%$ desired margin of error and $10 \%$ prevalence (percentage of farmers adopted the practice) using a formula for dichotomous outcome variable [49].

$$
S S=\frac{Z^{z} *(P) *(1-P)}{C^{z}}=\frac{(1.96)(1.96)(0.1)(1-0.1)}{(0.05)(0.05)}
$$

Where, SS = Sample Size Z = Z-value (1.96 for a 95\% confidence level), $\mathrm{P}=$ prevalence (Percentage of population expressed as decimal), $\mathrm{C}=$ Confidence interval $(\alpha)$, expressed as decimal. So that a total of 828 sample size were considered for the study from the six sample districts of the four regions.

A two-stage probability sampling method was used. In the first stage, all districts in the four regions that were targeted for disseminating the teff row planting practice using video based agricultural extension approach were considered as a sampling frame, from which a total of six districts were randomly selected. As a result Adaa (Oromia), Wolmera (Oromia), Debre Elias (Amhara), Dembia (Amhara), Meskan (SNNP) and Ofla (Tigray) districts were chosen for study. In the second stage, each sample district was considered as an independent sampling unit, and the participants from each sample district were selected using a simple random sampling method based on the list of participating farmers. A structured survey questionnaire aimed to measure perception and collected data on demographics, adoption status, reasons for adopting or not adopting the practice. In total, 828 surveys were collected, 138 from each of the selected districts. Approximately half (48\%) of respondents self-identified as model farmers. Model farmers are those who test or experiment new practices and technologies ahead of the majority do [50-54].

Data enumerators who are knowledgeable about the local context and respective regional languages were recruited and trained on administration procedures. The questionnaire was administered at participants homestead and data were collected in April, 2016. Data was checked for consistency and errors, double entered into Excel, and validated, which was analyzed using SPSS (version 20.0). Descriptive statistics (frequency distribution and percentages), Kruskal-Wallis Tests and biserial correlation were computed to understand farmer's perception towards teff row planting practice, adoption difference among farmers in different districts and to identify the significant perception factors affecting the adoption of teff on row planting [55-57].

Table 1 shows perception of respondents regarding the timeliness of the information disseminated on teff row planting. Among the total respondents $12.5 \%$ of the respondents have reported no/not timely, 14.8 were not sure if it was timely or not and $72.7 \%$ of the respondents perceive that the dissemination of was timely.

Table 1: Perception on timeliness of extension service.

\begin{tabular}{|c|c|c|}
\hline Description & Frequency & Valid Percent \\
\hline Not timely & 104 & 12.5 \\
\hline Not sure & 123 & 14.8 \\
\hline Yes & 601 & 72.7 \\
\hline Total & 828 & 100 \\
\hline
\end{tabular}

Table 2: Perception on labor requirements.

\begin{tabular}{|c|c|c|c|c|}
\hline \multicolumn{2}{|c|}{ Description } & Frequency & $\begin{array}{c}\text { Valid } \\
\text { Percent }\end{array}$ & $\begin{array}{c}\text { Cumulative } \\
\text { Percent }\end{array}$ \\
\hline \multirow{3}{*}{ Valid } & Not Consuming & 117 & 14.2 & 14.2 \\
\cline { 2 - 5 } & Fairly consuming & 182 & 22 & 36.2 \\
\cline { 2 - 5 } & Consuming & 528 & 63.8 & 100 \\
\cline { 2 - 5 } & Total & 827 & 100 & \\
\hline \multirow{2}{*}{ Missing } & System & 1 & & \\
\hline \multirow{2}{*}{ Total } & & 828 & & \\
\hline
\end{tabular}

Table 2 shows perception of respondents regarding the labor requirements of teff row planting. Among the total respondents 
$14.2 \%$ of the respondents have reported not consuming, $22.0 \%$ average and $63.8 \%$ of the respondents perceive that the practice of was labor consuming. The data shows that $85.8 \%$ of the respondents perceive that the labor requirement of practice is average and consuming.

Table 3 shows perception of respondents regarding the productivity of teff row planting. Among the total respondents $8.6 \%$ of the respondents have reported not relevant, 5.6\% not productive, $22.0 \%$ average and $63.8 \%$ of the respondents perceive that the practice of was productive. The data shows that $85.8 \%$ of the respondents perceive that the practice is productive more than average.

Table 3: Perception on productivity of the practice.

\begin{tabular}{|c|c|c|c|c|}
\hline \multicolumn{2}{|c|}{ Description } & Frequency & $\begin{array}{c}\text { Valid } \\
\text { Percent }\end{array}$ & $\begin{array}{c}\text { Cumulative } \\
\text { Percent }\end{array}$ \\
\hline \multirow{4}{*}{ Valid } & Not relevant & 71 & 8.6 & 8.6 \\
\cline { 2 - 5 } & Not productive & 46 & 5.6 & 14.2 \\
\cline { 2 - 5 } & Fairly productive & 182 & 22 & 36.2 \\
\cline { 2 - 5 } & Productive & 528 & 63.8 & 100 \\
\cline { 2 - 5 } & Total & 827 & 100 & \\
\hline \multirow{2}{*}{ Missing } & System & 1 & & \\
\hline Total & & 828 & 827 & \\
\hline
\end{tabular}

Table 4 shows perception of respondents regarding the contribution of the practice for the quality of the produce. Among the total respondents $2.7 \%$ of the respondents have reported not relevant, $1.7 \%$ not quality, $17.0 \%$ average and $78.6 \%$ of the respondents perceive that the practice contributed for quality of the produce. The data shows that $95.6 \%$ of the respondents perceive that the practice is quality above average.

Table 4: Perception on quality of the yield.

\begin{tabular}{|c|c|c|c|c|}
\hline \multicolumn{2}{|c|}{ Description } & Frequency & $\begin{array}{c}\text { Valid } \\
\text { Percent }\end{array}$ & $\begin{array}{c}\text { Cumulative } \\
\text { Percent }\end{array}$ \\
\hline \multirow{4}{*}{ Valid } & Not relevant & 22 & 2.7 & 2.7 \\
\cline { 2 - 5 } & Not quality & 14 & 1.7 & 4.4 \\
\cline { 2 - 5 } & Fair quality & 138 & 17 & 21.4 \\
\cline { 2 - 5 } & Quality & 639 & 78.6 & 100 \\
\cline { 2 - 5 } & Total & 813 & 100 & \\
\hline Missing & System & 15 & & \\
\hline Total & & 828 & & \\
\hline
\end{tabular}

Table 5 shows perception of respondents regarding the profitability of teff row planting practice. Among the total respondents $2.9 \%$ of the respondents have reported not relevant,
$1.4 \%$ not profitable, $21.3 \%$ average and $74.4 \%$ of the respondents perceive that the practice of was profitable. The data shows that $95.7 \%$ of the respondents perceive that the practice is profitable more than average.

Table 5: Perception on profitability of the produce.

\begin{tabular}{|c|c|c|c|c|}
\hline \multicolumn{2}{|c|}{ Description } & Frequency & $\begin{array}{c}\text { Valid } \\
\text { Percent }\end{array}$ & $\begin{array}{c}\text { Cumulative } \\
\text { Percent }\end{array}$ \\
\hline \multirow{4}{*}{ Valid } & Not relevant & 24 & 2.9 & 2.9 \\
\cline { 2 - 5 } & Not profitable & 11 & 1.4 & 4.3 \\
\cline { 2 - 5 } & Fair & 171 & 21.3 & 25.6 \\
\cline { 2 - 5 } & Profitable & 598 & 74.4 & 100 \\
\cline { 2 - 5 } & Total & 804 & 100 & \\
\hline Missing & System & 24 & & \\
\hline Total & & 828 & & \\
\hline
\end{tabular}

Table 6 shows adoption status of the respondents. Among the total respondents $42.3 \%$ of the respondents were not adopted the practice whereas the remaining $57.7 \%$ of the respondents adopted the practice.

Table 6: Adoption status.

\begin{tabular}{|c|c|c|}
\hline Description & Frequency & Valid Percent \\
\hline Not adopted & 350 & 42.3 \\
\hline Adopted & 478 & 57.7 \\
\hline Total & 828 & 100 \\
\hline
\end{tabular}

As indicated on Table 7 adoption status varies across districts with the highest $85.5 \%$ in Ofla district whereas the lowest 30.43\% in Wolmera district. Among the six districts the adoption status of the three districts (Adaa, wolmera and Meskan) found to below the mean adoption of the sample mean.

Table 7: District * Adoption status Cross tabulation.

\begin{tabular}{|c|c|c|c|c|c|}
\hline \multicolumn{2}{|c|}{$\begin{array}{c}\text { Descriptions } \\
\text { No }\end{array}$} & \multicolumn{2}{c|}{ Adoption status } & \multirow{2}{*}{ Total } & \multirow{2}{*}{ \% adopted } \\
\cline { 2 - 6 } & Adaa & 91 & 47 & 138 & 34.06 \\
\hline \multirow{4}{*}{ District } & Debre Elias & 46 & 92 & 138 & 66.67 \\
\cline { 2 - 6 } & Dembia & 34 & 104 & 138 & 75.36 \\
\cline { 2 - 6 } & Meskan & 62 & 76 & 138 & 55.07 \\
\cline { 2 - 6 } & Ofla & 20 & 118 & 138 & 85.5 \\
\cline { 2 - 6 } & Wolmera & 96 & 42 & 138 & 30.43 \\
\hline \multirow{7}{*}{ Total } & & 293 & 350 & 478 & \\
\hline
\end{tabular}

As indicated on Table 8 Kruskal-Wallis Tests result shows that there is significant difference among districts in adopting teff row planting practice.

Table 8: Kruskal-Wallis Tests.

\begin{tabular}{|c|c|c|c|}
\hline Null Hypothesis & Test & Sig & Decision \\
\hline $\begin{array}{l}\text { The distributions of adoption status is the same across categories of districts Asymp- } \\
\text { totic significances are displayed. The significance level is .05 }\end{array}$ & $\begin{array}{l}\text { Independent sample } \\
\text { Kruskal -Wallies test }\end{array}$ & 0 & $\begin{array}{l}\text { Reject the null hypoth- } \\
\text { esis }\end{array}$ \\
\hline
\end{tabular}

Table 9 above shows respondents' response for adopting $45.6 \%$ because the practice is productive, $19.7 \%$ because they teff row planting. Among the total respondents $10.9 \%$ of the respondents have reasoned that the practice requires less labor, received sufficient training, $2.9 \%$ having adequate funds and $20.9 \%$ of the respondents perceive that the practice of was useful. 


\section{Agricultural Research \& Technology: Open Access Journal}

The major portion (45.6\%) of the respondents were adopted the practice because they perceived that the practice is productive.

Table 9: Reason for adopting the practice (multiple reason possible).

\begin{tabular}{|c|c|c|c|}
\hline \multicolumn{2}{|c|}{ Descriptions } & Frequency & Valid Percent \\
\hline \multirow{4}{*}{ Valid } & It requires less labor & 52 & 10.9 \\
\cline { 2 - 4 } & Productive & 218 & 45.6 \\
\cline { 2 - 4 } & Received sufficient training & 94 & 19.7 \\
\cline { 2 - 4 } & Adequate funds & 14 & 2.9 \\
\cline { 2 - 4 } & It is useful & 100 & 20.9 \\
\hline Total & & 478 & 100 \\
\hline
\end{tabular}

As indicated in Table 10 above the major reason for not adopting the practice were the farmers perceives that the practice was labor consuming, capacity gap and shortage of money. The major reason mentioned was $94.6 \%$ of the farmers perceives that the practice is labor consuming.

Table 10: Major reason for not continuing adopting in the future.

\begin{tabular}{|c|c|c|}
\hline Description & Frequency & Valid Percent \\
\hline Labor consuming & 87 & 94.6 \\
\hline Capacity gap & 2 & 2 \\
\hline Shortage of Money & 1 & 1.4 \\
\hline Other & 2 & 1.9 \\
\hline Total & 92 & 100 \\
\hline
\end{tabular}

Table 11 shows level of Interest to recommend the practice for other peer farmers. As indicated in the table above $86.3 \%$ of the farmers who adopted the practice were willing to recommend the practice to other peer farmers at least moderately.

Table 11: Interest to recommend the practice for other peer farmers (Strength1-5 like rt level).

\begin{tabular}{|c|c|c|c|c|}
\hline \multicolumn{2}{|c|}{ Description } & Frequency & $\begin{array}{c}\text { Valid } \\
\text { Percent }\end{array}$ & Cumulative Percent \\
\hline \multirow{4}{*}{ Valid } & Not at all & & 9.7 & 9.7 \\
\cline { 2 - 5 } & Some how & & 8 & 17.6 \\
\cline { 2 - 5 } & Moderately & & 17 & 34.7 \\
\cline { 2 - 5 } & Strongly & & 29 & 63.7 \\
\cline { 2 - 5 } & Very strongly & & 36.3 & 100 \\
\hline & Total & & 100 & \\
\hline
\end{tabular}

As indicated on Table 12 above that the correlation coefficient between the dependent variable adoption status and independents variables perceived model/none model status, timeliness, labor requirements, productivity, quality of the produce, easiness to understand the practice and profitability shows that perceived model/none model status ,perceived productivity of the practice, quality of the produce and easiness to understand the practice found to be significantly correlated with adoption status.

Table 12: Inter correlation matrix among adoption status and independent variables.

\begin{tabular}{|c|c|c|c|c|c|c|c|c|}
\hline \multicolumn{2}{|r|}{ Description } & \multirow{2}{*}{$\begin{array}{c}\text { Model/Non-Model } \\
\text { Status } \\
.171^{* *}\end{array}$} & \multirow{2}{*}{$\begin{array}{c}\text { Timeliess s } \\
0.009\end{array}$} & \multirow{2}{*}{$\begin{array}{c}\text { Labor req. } \\
-0.044\end{array}$} & \multicolumn{2}{|c|}{ Product. Quality } & \multirow{2}{*}{$\begin{array}{c}\begin{array}{c}\text { Easy to Under- } \\
\text { stand }\end{array} \\
.065^{*}\end{array}$} & \multirow{2}{*}{$\begin{array}{c}\text { Profitability } \\
0.04\end{array}$} \\
\hline \multirow{3}{*}{$\begin{array}{c}\text { Adop- } \\
\text { tion }\end{array}$} & Biserial Correlation & & & & $.157^{* *}$ & $.053^{*}$ & & \\
\hline & Sig. (2-tailed) & 0 & 0.724 & 0.102 & 0 & 0.043 & 0.015 & 0.134 \\
\hline & $\mathrm{N}$ & 828 & 828 & 780 & 828 & 760 & 827 & 740 \\
\hline \multicolumn{9}{|c|}{${ }^{* *}$ Correlation is significant at the 0.01 level (2-tailed). } \\
\hline \multicolumn{9}{|c|}{${ }^{*}$ Correlation is significant at the 0.05 level (2-tailed). } \\
\hline
\end{tabular}

\section{Discussion}

The main objective of this study was to assess farmers' perceptions regarding teff row planting and how these perceptions affects adoptions of the practice and also to analyze adoption differences across six districts of the four (Amhara, Oromia, SNNP and Tigray) regional states of Ethiopia.

The result of the current study showed that majority of the farmers in the study area have positive perception to teff row planting practice except it's intensive labor requirements. The result shows that $85.8 \%$ of the farmers perceive that the practice is labor intensive, $95.6 \%$ of the farmers perceive that the practice is profitable, $85.8 \%$ of the respondents perceive that the practice productive, $95.7 \%$ of the respondents perceive that the practice is profitable and $95.6 \%$ of the respondents perceive that the practice is quality. However, among the total respondents only $57.7 \%$ of the respondents adopted the practice. According to the response given by non-adopting farmers, among the total respondents $(n=350)$ $6.4 \%$ reasoned that it consumes labor, $41.1 \%$ not productive, $22.9 \%$ not receiving sufficient training, $17.0 \%$ because it is not useful and $2.6 \%$ non-availability of inputs. Among those farmers who adopted the practice this year $(n=478) 19.2 \%$ of them were not willing to adopt in the next season; and also $9.7 \%$ of the farmers were not at all willing to recommend the practice to other peer farmers. This implies that trainings, labor requirement of the practice and availability of inputs are the major factors affecting adoption status of the practice in the study area.

Based on the magnitude and sign $(-/+)$ of correlation coefficient among the dependent variable (adoption status) and the independent variables perceived model/non-model status, timeliness, labor requirements, productivity, quality of the produce, easiness to understand the practice and profitability; the finding implies that perceived model/non-model status ,perceived productivity of the practice, quality of the produce and easiness to understand the practice found to be significantly correlated with adoption status.

Based on the summary of the findings indicated above, the researcher draws the following conclusions, and their corresponding implications: 
a. The result of the current study showed that majority of the farmers in the study area have positive perception to teff row planting practice except its intensive labor requirements.

b. The findings also indicated that significant number of farmers were not adopted the practice though they perceived it positive in most of perception parameters pursued and also there is significant difference among districts in adopting teff row planting practice. This implies that adoption status was still affected by other unforeseen perception and nonperception factors.

c. However, the current adoption status is promising in most study districts it likely to be slowed by its technical challenges: given the small size of the teff seed, it is challenging to properly calibrate the seed rate and labor- intensive to manage manually.

d. The result also revealed that perceived model/nonmodel status, perceived productivity of the practice, quality of the produce and easiness to understand the practice found to be significantly correlated with adoption status. This implies that if an intended practice is easy to be understood by the farmers and able to create positive impression on increasing productivity and quality of the produce the likelihood of being adopted by the farmers is high.

\section{Recommendation}

This research explored the status of adoptions, perceived reasons for adopting and not adopting the practice and it also pinpointed some of the perception factors significantly correlated with adoption. In the light of these findings, the following recommendations are forwarded in order to improve uptake of teff row planting practice and benefits gained from row planting practice in the process of teff grain production.

a. Organizations working on promoting teff row planting practice should craft their message in such a way that the theme of the message emphasize on its contribution on productivity and quality of the produce and also should make the content of the message simple and easily understood by the farmers.

b. To ensure sustainability of adoption and improve uptake of teff row planting practice row planting is most effectively carried out with a planting machine, which controls the seed rate. It necessary be supported with small holder farmer friendly, efficient and cost effective and mechanization technology.

\section{Acknowledgement}

I wish to thank Darian Schiffman for her assistance, ideas, and feedback as well as Digital Green.

\section{References}

1. Belay K (2003) Agricultural Extension in Ethiopia: The Case of Participatory Demonstration and Training Extension System. Journal of Social Development in Africa 18: 49-84.
2. Spielman D, Dawit M, Dawit A (2012) Seed, Fertilizer and Agricultural Extension in Ethiopia. In: Paul Dorosh, Shahidur Rashid (eds.), Food and Agriculture in Ethiopia. Philadelphia: University of Pennsylvania Press. pp. 256-279.

3. Mosher BW, Robert A Duce (1987) A global atmospheric selenium budget. JGR Atmospheres 92(D11): 13289-13298.

4. Rogers EM (1983) Diffusion of innovations ( $3^{\text {rd }}$ ed), The Free Press: New York, USA, p. 236.

5. Valera FR, Berraquero FR, Cormenzana AR (1981) Characteristics of the heterotrophic bacterial populations in hypersaline environments of different salt concentrations. Microbial Ecology 7(3): 235-243.

6. Kebede Y, Gunjal K, Coffin G (1990) Adoption of New Technologies in Ethiopian Agriculture: The Case of Tegulet-Bulga District, Shoa Province. Agricultural Economics 4(1): 27-43.

7. Meijer SS, Catacutan D, Ajayi OC, Sileshi GW, Nieuwenhuis M (2014) The Role of Knowledge, Attitudes and Perceptions in the Uptake of Agricultural and Agroforestry Innovations among Smallholder Farmers in Sub-Saharan Africa. International Journal of Agricultural Sustainability 13(1): 40-54.

8. Feder G, Slade R (1984) The acquisition of information and the adoption of new technology. Amer. J of Agric Econ 66(3): 312-320.

9. Shampine A (1998) Compensating for information externalities in technology diffusion models. Amer. J of Agric Econ 80(3): 337-346.

10. Smale M, Just R, Leathers HD (1994) Land Allocation in HYV Adoption Models: An Investigation of Alternative Explanations. Amer. J of Agric Econ 76(3): 535-546.

11. Aikens MT, Havens AE, Flinn WL (1975) The adoption of innovations: the neglected role of institutional constraints. Mimeograph. Department of Rural Sociology. The Ohio State University. Columbus, Ohio.

12. Kivlin JE, Fliegel FC (1967) Differential perceptions of innovations and rate of adoption. Rural Sociology 32(1): 78-91.

13. Ashby JA, Quirose CA, Rivers YM (1989) Farmer participation in technology development: Work with crop varieties. In: Chabers, $\mathrm{R}$, Pacey A, et al. (Eds.), Farmer first. Farmer innovations and agricultural research. Intermediate technology publications, London, UK.

14. Ashby JA, Sperling L (1992) Institutionalizing participatory, clientdriven research and development in agriculture. Centro Internacional de Agricultura Tropical. p. 20.

15. Adesina AA, Zinnah M (1992) Technology Characteristics, Farmers' Perception and Adoption Decision: A Tobit model Application in Sierra Leone. Agricultural Economics 9(4): 297-311.

16. Adesina A, Baidu-Forson J (1995) Farmers' perception of new agricultural technology evidence from analysis in Burkina Faso and Guinea, West Africa. Agricultural Economics 13(1): 1-9.

17. Farrington J, Martin A (1989) Farmer participation in agricultural research: A review of concepts and practices. Food Policy 14(2): 97100.

18. Byerlee D, Collinson MP, Winkelmann D, Biggs S, Moscardi ER, et al. (1988) Planning technologies appropriate to farmers: concepts and procedures. CIMMYT, p. 71.

19. Chambers R, Pacey A, Thrupp LA (1989) Farmer first: Farer innovations and agricultural research. Intermediate Technology Publications 10(4): 474-475.

20. Tripp Robert (1989) Farmer Participation in Agricultural Research: New Directions or Old Problems? Brighton, England: Institute of Development Studies Discussion. Paper. p. 35.

21. Gandhi R, Veeraraghavan R, Toyama K, Ramprasad V (2009) Digital Green: Participatory Video for Agricultural Extension. Information Technologies for International Development 5(1): 1-15. 
22. Teklu Y, Tefera H (2005) Genetic Improvement in Grain Yield Potential and Associated Agronomic Traits of Tef (Eragrostis Tef). Euphytica 141(3): 247-254.

23. CSA (2015) Agricultural Sample Survey: Area and Production of Major Crops, Meher Season, Vol. I. Central Statistics Agency: Addis Ababa, Ethiopia.

24. Berhe T, Gebretsadik Z, Edwards S, Araya H (2011) Boosting Tef Productivity Using Improved Agronomic Practices and Appropriate Fertilizer. In: Assefa K, Solomon T, et al. (Eds.), Achievements and Prospects of Tef Improvement. Proceedings of the Second International Workshop, Debre Zeit, Ethiopia.

25. ATA (Agricultural Transformation Agency) (2013) Results of $2012 \mathrm{New}$ Tef Technologies Demonstration Trials Draft Report VF. Agricultural Transformation Agency: Addis Ababa, Ethiopia.

26. Fufa B, Behute B, Simons R, Berhe T (2011) Strengthening the Tef Value Chain in Ethiopia. Addis Ababa: Agricultural Transformation Agency.

27. Berhane G, Paulos Z, Tafere K (2011) Food grain Consumption and Calorie Intake Patterns in Ethiopia. ESSPII Working Paper 23. International Food Policy Research Institute (IFPRI): Addis Ababa, Ethiopia.

28. ATA (Agricultural Transformation Agency) (2013b) Working Strategy for Strengthening Ethiopian's Tef Value Chain Vision, Systemic Challenges, and Prioritized Interventions. Agricultural Transformation Agency: Addis Ababa, Ethiopia.

29. ATA (Agricultural Transformation Agency) (2012) Annual Report: Transforming Agriculture in Ethiopia. Agricultural Transformation Agency: Addis Ababa, Ethiopia.

30. Vandercasteelen J, Dereje M, Minten B, Taffesse AS (2013) Scaling-up Adoption of Improved Technologies: The Impact of the Promotion of Row Planting on Farmers' Teff Yields in Ethiopia. International Food Policy Research Institute, ESSP Working Paper 60. p. 28.

31. Vandercasteelen J, Dereje M, Minten B, Taffesse AS (2014) Perceptions, Impacts and Rewards of Row Planting of Teff. International Food Policy Research Institute, ESSP Working Paper 65. p. 23.

32. Vandercasteelen J, Dereje M, Minten B, Taffesse AS (2013b) The Impact of the Promotion of Row Planting on Farmers' Teff Yields in Ethiopia. International Food Policy Research Institute, ESSP Research Note 27. p. 2.

33. Taffesse AS, Dorosh P, Gemessa SA (2012) Crop production in Ethiopia: Regional patterns and trends. In: Dorosh P, Rashid S (eds.), Food and Agriculture in Ethiopia: Progress and Policy Challenges. University of Pennsylvania: Philadelphia, USA, p. 2.

34. Yu B, Nin-Pratt A (2014) Fertilizer Adoption in Ethiopia Cereal Production. Journal of Development and Agricultural Economics 6(7): 318-337.

35. Ahmed MH (2014) Farmer's Decision to Practice Crop Rotation in Arsi Negelle, Ethiopia: What are the Determinants? International Journal of Sustainable Agricultural Research 1(1): 19-27.

36. Waddington H, White H (2014) Farmer Field Schools: From Agricultural Extension to Adult Education. International Initiative for Impact Evaluation (3ie), Systematic Review Summary 1.

37. Feder G, Murgai R, Quizon JB (2004) Sending Farmers Back to School: The Impact of Farmer Field Schools in Indonesia. Review of Agricultural Economics 26(1): 45-62.

38. Van den Berg H (2004) IPM Farmer Field Schools: A synthesis of 25 Impact Evaluations.
39. Feder G, Murgai R, Quizon JB (2008) Investing in Farmers - The Impacts of Farmer Field Schools in Relation to Integrated Pest Management - A Comment. World Development 36(10): 2103-2106.

40. Van den Berg H, Jiggins J (2007) Investing in Farmers - The Impacts of Farmer Field Schools in Relation to Integrated Pest Management. World Development 35(4): 663-686.

41. Yamazaki S, Resosudarmo BP (2007) Does Sending Farmers Back to School Have an Impact? A Spatial Econometric Approach. Australian National University Working Paper 2007/03.

42. Waddington H, Snilstveit B, Hombrados J, Vojtkova M, Phillips D, et al. (2014) Farmer Field Schools: From Agricultural Extension to Adult Education. Making Impact Matter, Manila $1^{\text {st }}-5^{\text {th }}$ September. p. 35.

43. Ali M, Peerlings J (2012) Farm Households and Nonfarm Activities in Ethiopia: Does Clustering Influence Entry and Exit? Agricultural Economics 43(3): 253-266.

44. Mekuria W (2014) Effectiveness of Modular Training at Farmers; Training Center: Evidence from Forega District, South Gondar Zone, Ethiopia. American Journal of Rural Development 2(3): 46-52.

45. Limenih B, Tefera T (2014) Knowledge Gaps in Potato Technology Adoption: The Case of Central Highlands of Ethiopia. Journal of Agricultural Extension and Rural Development 6(8): 259-266.

46. Cochrane L (2017) Worldviews Apart: Agricultural Extension and Ethiopian Smallholder Farmers. Journal of Rural Social Sciences. 32(1): 98-118.

47. Ersado L, Amacher G, Alwang J (2004) Productivity and Land Enhancing Technologies in Northern Ethiopia: Health, Public Investments, and Sequential Adoption. American Journal of Agricultural Economics 86(2): 321-331.

48. Rogers EM, Shoemaker FF (1971) Communication of Innovations: A Cross - Cultural Approach. ( $2^{\text {nd }}$ edn), The Free Press. New York, USA.

49. Godden B (2004) Sample Size Formulas. Journal of Statistics 3: 1.

50. Beyene Y, Botha AM, Myburg A (2005) Genetic Diversity in Traditional Ethiopian Highland Maize Accessions Accessed by AFLP Markers and Morphological Traits. Biodiversity and Conservation 15(8): 26552671.

51. Byerlee D, Hesse de Polanco E (1986) Farmers' stepwise adoption of technological packages: evidence from the Mexican Altipalno. American Journal of Agricultural Economics 68(3): 519-527.

52. Biggs S (1980) Informal R\&D. Ceres 13(4): 23-26.

53. Bonger T, Ayele G, Kuma T (2004) Agricultural Extension, Adoption and Diffusion in Ethiopia. Addis Ababa: Ethiopia.

54. Fufa Hundera, Tesfaye Bogale, Hailu Tefera, Kebebew Asefa, Tiruneh Kefyalew, et al. (2001) Agronomy Research in Tef. In: Hailu Tefera, Getachew Belay, et al. (Eds.), Narrowing the Rift: Tef Research and Development. Ethiopian Agricultural Research Organization (EARO), Addis Ababa, Ethiopia.

55. Samberg L, Fishman L, Allendorf FW (2013) Population Genetic Structure in a Social Landscape: Barley in a Traditional Ethiopian Agricultural System. Evol Appl 6(8): 1133-1145.

56. Tsegaye D, Vedeld P, Moe SR (2013) Pastoralists and Livelihoods: A Case Study from Northern Afar, Ethiopia. Journal of Arid Environments 91: 138-146.

57. Yosef T, Mengistu U, Solomon A, Mohammed YK, Kefelegn K (2013) Camel and Cattle Population Dynamics and Livelihood Diversification as a Response to Climate Change in Pastoral Areas of Ethiopia. Livestock Research for Rural Development 25(9): 1-10. 
This work is licensed under Creative

Commons Attribution 4.0 License

DOI: 10.19080/ARTOAJ.2018.19.556078

\section{Your next submission with Juniper Publishers will reach you the below assets}

- Quality Editorial service

- Swift Peer Review

- Reprints availability

- E-prints Service

- Manuscript Podcast for convenient understanding

- Global attainment for your research

- Manuscript accessibility in different formats

( Pdf, E-pub, Full Text, Audio)

- Unceasing customer service

Track the below URL for one-step submission https://juniperpublishers.com/online-submission.php 